\title{
Posterior reversible encephalopathy syndrome (PRES) の治療経験
}

\author{
門野 紀子 大地史広 出口志保 日下 裕介 \\ 下山雄一郎 日外知行梅垣修
}

大阪医科大学集中治療部 ( T 569-8686 大阪府高梘市大学町 2-7)

Key words: (1) posterior reversible encephalopathy syndrome (PRES), (2) hypertension, (3) visual abnormalities

\section{はじめに}

脳血管は脳血流自動調節能を有する。この上限を超 えて血圧が上昇すると脳血流は異常に増加し, 脳浮腫 が生じる。このような病態は高血圧脳症として知られ ている1)。このうち1996年にHincheyらが, MRI画 像で両側後頭葉を中心に T2強調像で高信号を示すも のを posterior reversible encephalopathy syndrome (PRES) と報告した ${ }^{2)}$ 。

今回我々は, 上顎癌の化学療法中にPRESを認めた 症例を経験したので報告する。

\section{症 例}

症例：56歳, 男性。身長 $174 \mathrm{~cm}$, 体重 $69 \mathrm{~kg}$ 。

既往歴および家族歴：特記事項なし。

現病歴：左上顎癌 (扁平上皮癌 pT3N0M0, stage III) に対し化学療法 (cisplatin $80 \mathrm{mg} / \mathrm{m}^{2} /$ day, 5-fluorouracil $800 \mathrm{mg} / \mathrm{m}^{2} /$ day $\times 5$ 日間持続静注)を行ってい た。化学療法開始後 10 病日に急性腎不全を発症した。 24病日からは血圧の上昇 (収縮期血圧 $170 \sim 180$ $\mathrm{mmHg}$ )を認めていた。

26 病日には視野欠損が出現した。頭蓋内病変を疑 いCT, MRIを撮影した。MRI撮影待機中, 呼吸状態 が悪化した。痤攣発作をきたしたため, 気管挿管を行 い人工呼吸管理とした。MRI撮影後ICUに入室した。

入室時現症：意識レベル JCS III -300, 血圧 192/85 $\mathrm{mmHg}$, 心拍数 $95 / \mathrm{min}$, 体温 $35.8^{\circ} \mathrm{C}$, 瞳孔不同 $(-)$ ピンホール大, 心電図正常範囲。
血液 ·生化学所見 : Cr $4.59 \mathrm{mg} / \mathrm{d} l, \mathrm{CRP} 3.55 \mathrm{mg} / \mathrm{d} l$ と上昇。

血液ガス所見: Synchronized intermittent mandatory ventilation (SIMV) + pressure support (PS) モードで，正常範囲内。

頭部MRI画像で両側後頭葉に高信号領域を認めた (Fig. 1)。

入室後経過：二カルジピン塩酸塩で降圧を図った。 呼吸管理中の鎮静薬としてデクスメデトミジン塩酸塩 およびプロポフォールを使用した。抗痤攣薬にジフェ ニルヒダントインを投与した。脳浮腫予防として 10\%グリセリンを投与した。

入室 1 日後Richmond Agitation-Sedation Scale (RASS)-1を確認, 意識レベルが改善したと推測され た。3日後に $\mathrm{F}_{\mathrm{I}} \mathrm{O}_{2} 0.21$, proportional assist ventilation $25 \%$ モードで呼吸回数 $12 / \min$ の設定で, 血液ガスで $\mathrm{PaO}_{2} 107$ mmHg, $\mathrm{PaCO}_{2} 33.5$ mmHg まで改善したた め抜管した。 4 時間後, 酸素マスク $4 \mathrm{l} / \mathrm{min}$ で呼吸状態 が安定していたので退室となった。

急性腎不全については入室後も Cr 高值 $(3.39$ $\mathrm{mg} / \mathrm{d} l)$ が続いていた。1日尿量は2,000〜2,900 m $l$ だった。

発症 13 日後, MRI画像上で両側後頭葉の浮腫性変 化は改善し, 神経学的な症状は残存せず軽快した。

\section{考 察}

PRESは1996年Hincheyらが提唱した疾患概念で あり 2), 高血圧脳症のうちMRI画像上, 後頭葉の白質

Treatment of a case of posterior reversible encephalopathy syndrome (PRES)

Noriko Kadono, Fumihiro Ohchi, Shiho Deguchi, Yusuke Kusaka, Yuichiro Shimoyama, Tomoyuki Agui, Osamu Umegaki Intensive Care Unit, Osaka Medical College Hospital(2-7 Daigaku-machi, Takatsuki, Osaka 569-8686, Japan)

J Jpn Soc Intensive Care Med 2015;22:267-8. 


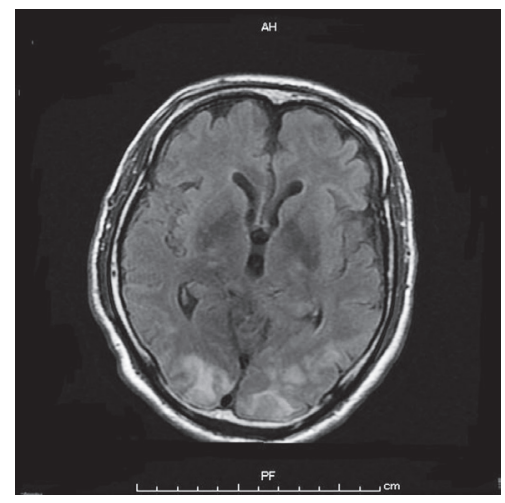

Fig. 1 MRI findings on admission to the ICU Hyperintense lesions were observed in the bilateral occipital-parietal lobes.

に高信号を認めることを特徵とした, 高血圧脳症の 1 分類として報告が増加している1)。

PRESでは高血圧, 産裖子疰, 化学療法 ${ }^{3)}$, 免疫抑制 薬使用 ${ }^{4)}$, 腎障害, 自己免疫疾患などを背景に, 脳血流 の自動調節能不全や血管内皮細胞の傷害が起こると考 えられている。さらに血液脳関門が破綻して血管原性 浮腫を起こすことが, PRESの原因であると考えられ ている5) 7)。今回の症例における発症の原因として は化学療法, 腎障害, 悪性腫瘍など複数の因子が考え られた。

病因には諸説あり, 血圧の急激な上昇による脳血流 の自動調節能不全, 細胞毒性物質の循環による脳血管 内皮細胞傷害, 脳血管攣縮による脳血流低下や脳梗塞 などが挙げられている5) 7)。また後頭部に好発する 原因として, 後頭部領域の血管は前頭部領域より交感 神経支配が弱いので, より脳循環自動調節能の影響を 受けやすいためと考えられている5),6)。PRESは原因 となっている病態が解消されると臨床的, 画像的異常 が可逆的に消失し, 後遺症を残さないことがほとんど である7)。

PRESでは症状として高血圧に加えて, 頭痛, 嘔吐, 視覚障害, 痤攣, 意識障害などをきたし, 12〜48時間 で症状が悪化する3)。診断には頭部MRI〔T2強調像, fluid attenuated inversion recovery (FLAIR) 画像, 拡散強調像]画像検査が推奨されている ${ }^{6)}$ 。CT撮影 のみでのPRESの診断は $50 \%$ といわれている8)。

今回の症例では眼症状から頭蓋内病変を疑い, MRI を撮影した。早期に頭部MRI画像検査を行い, 脳梗塞, 中毒性や代謝性の脳症, 脱髄性疾患, 血管炎, 脳炎な どを鑑別診断し対応することが重要である。

PRESは急性発症が多く, 発症予測は難しい。その 病態は必ずしも高血圧や子痭を合併するものでない。
臨床症状から総合的に疑うものであるとの報告もあ る9)。

治療は速やかな降圧と抗脳浮腫薬, 抗痤攣薬の投与 である10)。10\%グリセリン静脈内投与の脳浮腫に対 する予防効果の報告はない。MRI画像上脳圧立進所 見のない本症例に使用したことについての有効性は不 明である。

PRESは原因が多彩である。しかし, 早期に頭部 MRIを撮影することにより診断を下すことができる 可能性がある。

\section{結 語}

PRESは, 高血圧脳症のうち画像上脳浮腫と思われ る病変が後部大脳白質を中心に認められる疾患概念で ある。早期の頭部MRI撮影を行い, 診断することが重 要である。

本稿の要旨は, 第 41 回日本集中治療医学会学術集会 (2014，京都) で発表した。

本稿の全ての著者には規定されたCOIはない。

\section{文 献}

1) 渡邊雅彦. 高血圧性脳症. 医と薬学 2012;68:211-5.

2) Hinchey J, Chaves C, Appignani B, et al. A reversible posterior leukoencephalopathy syndrome. N Engl J Med 1996;334:494-500.

3) 戸田孝祐, 柿原直樹, 庽 賢, 他. TS-1+Cisplatin併用療法 中に可逆性後部白質脳症症候群を発症した高度進行胃癌の 1例. 日消外会誌 2010;43:365-9.

4) 丸田豊明, 丸田 望, 三浦弘樹, 他. シクロスポリンが原 因で posterior reversible encephalopathy syndromeを発 症した小児の 1 症例. 日集中医誌 2004;11:455-9.

5) 伊藤泰広, 河合 真, 安田武司. Reversible posterior leukoencephalopathy syndrome (RPLS) / posterior reversible encephalopathy syndrome (PRES) をお忘れな <. 日集中医誌 2008;15:480-4.

6) Roth C, Ferbert A. The posterior reversible encephalopathy syndrome: what's certain, what's new? Pract Neurol 2011;11:136-44.

7) Bartynski WS. Posterior reversible encephalopathy syndrome, part 1: fundamental imaging and clinical features. AJNR Am J Neuroradiol 2008;29:1036-42.

8) Roth C, Ferbert A. Posterior reversible encephalopathy syndrome: long-term follow-up. J Neurol Neurosurg Psychiatry 2010;81:773-7.

9) 庄とも子, 吉村和晃, 柴田英治, 他. 当科で経験したPRES (posterior reversible encephalopathy syndrome) 症例の検 討. 日周産期・新生児会誌 2011;47:623-8.

10) Servillo G, Bifulco F, De Robertis E, et al. Posterior reversible encephalopathy syndrome in intensive care medicine. Intensive Care Med 2007;33:230-6. 採択日 2014 年 10 月 14 日 